\section{Classification of a diffuse heavy metal polluted mining site using a spectral angle mapper}

\author{
Attila Nagy - János Tamás \\ University of Debrecen, Centre of Agricultural Sciences, \\ Faculty of Agronomy, Dept. of Water and Environmental \\ Management, Debrecen \\ anagy@gisserver1.date.hu
}

\section{SUMMARY}

Characterization of heavy metal polluted abandoned mining sites is complicated, as the spatial distribution of pollutants often changes dramatically.

In our study, a hyperspectral data analysis of the Gyöngyösoroszi abandoned $\mathrm{Pb}-\mathrm{Zn}$ mine, located in northern Hungary, where Záray (1991) reported serious heavy metal contamination, was carried out using ENVI 4.3. In this area, galena $(\mathrm{PbS})$, goethite $(\mathrm{FeO}(\mathrm{OH}))$, jarosite $\left(\mathrm{KFe}_{3}\left(\mathrm{SO}_{4}\right)_{2}(\mathrm{OH})_{6}\right)$, sphalerite $((\mathrm{Zn}, \mathrm{Fe}) \mathrm{S})$ and pyrite $\left(\mathrm{FeS}_{2}\right)$ were the predominant minerals in the alteration zones was chosen as the target mineral. Spectral angle mapper (SAM) and BandMax classification techniques were applied to obtain rule mineral images. Each pixel in these rule images represents the similarity between the corresponding pixels in the hyperspectral image to a reference spectrum.

As a result of hyperspectral imagery the distribution of pyritic minerals (sphalerite, galena) in the area was defined. Both of the mineral formations occur, especially in mine tailings, the area of the ore preparatory, and the Szárazvölgyi flotation sludge reservoir. According to the results, jarosite and goethite have similar distributions to sphalerite and galena. The results showed that hyperspectral remote sensing is an effective tool for the characterization of $\mathrm{Pb}, \mathrm{Zn}$ and $\mathrm{Fe}$ containing minerals at the examined polluted sites and for modelling the distribution of heavy metals and minerals in extensive areas.

This classification method is a basis of further detailed investigations, based on field measurements, to map the heavy metal distribution of the studied area and to quantify the environmental risks caused by erosion, which include DEM (digital elevation model) and climatic and hydrological data sources. Furthermore, it can be used primarily to support the potentially applicable phytostabilization technique and to isolate hot spots where only ex-situ remediation techniques can be applied.

Keywords: hyperspectral image, SAM classification, heavy metal containing minerals

\section{INTRODUCTION}

The characterization of heavy metal polluted abandoned mining sites is a complicated assignment due to the variable spatial distribution of the pollutants. Therefore, a complex integrated method is required in order to assess precisely the amount and the distribution of the contaminants. Several publications dealt with acid mine drainage (Szucs et al., 2002; Yan and Bradshaw, 1995) and soil plant systems for characterization of the distribution of heavy metals (Kabata-Pendias, 2001; Csathó, 1994;
Abdorhim et al., 2004; Kádár, 1991), but the assessment of heavy metal distribution by mapping technologies has not been well studied. Several publications dealt with the successful application and the advantages of hyperspectral remote sensing (Kardeván et al., 2003; Juhász et al., 2004; Burai, 2006).

Remote sensing is the science of acquiring, processing, and interpreting images and related data, acquired from aircraft and satellites, that record the interaction between matter and electromagnetic energy (Sabins, 1997). Remote sensing imagery has contributed significantly to mineral exploration. For example, mapping of geological faults and fractures that localize ore deposits and recognize hydrothermally-altered rocks based on their spectral signatures (Sabins, 1999). A major problem with remote sensing approaches to mineral exploration using broad-band multispectral sensors is the insufficient spectral resolution to map hydrothermal alteration minerals, which exhibit subtle differences in spectral signatures (Clark, 1999).

Small bandwidths distinguish hyperspectral sensors from multispectral sensors, acquiring spectral information of materials usually over several hundreds of narrow contiguous spectral bands, with high spectral resolution on the order of $20 \mathrm{~nm}$ or narrower (Polder and van der Heijden, 2001). As such, they allow identification of specific materials, whereas broadband multispectral data only allow discrimination between classes of materials (Kruse et al., 2003).

The examined area is a flotation sludge reservoir of an abandoned $\mathrm{Pb}-\mathrm{Zn}$ mining site located in Gyöngyösoroszi, Northern Hungary, where Záray (1991) reported serious heavy metal contamination. At the examined site, the properties and the contents of the mine tailings are different, due to their different technological origin. At the same time, the terrain and hydrological properties are also variable (Jordan and D'Alessandro, 2004) contributing to water erosion of the mining tails, which results diffuse heavy metal contamination of the surrounding area. The hyperspectral images of the flotation sludge reservoir were obtained by using a Digital Airborne Imaging Spectrometer DAIS 7915, in the frame of DLR HySens first Hungarian hyperspectral flight campaign (21/08/2002). The DAIS 7915 sensor is a 79-channel high-resolution optical airborne imaging spectrometer which collects information in five blocks of contiguous channels in the wavelength region of 0,4 to $12,3 \mu \mathrm{m}$. The DAIS sensor recorded 
spectra at SWIR I,II (1.5-1.8; 2.0-2.5), which was used for the determination of heavy-metal containing minerals, and the spectrum of VIS/NIR (0.43-1.05) was used for providing spectral information on uncovered surface and the biomass of the area (Kardeván et al., 2003).

The present study aims to use the Spectral Angle Mapper (SAM) with BandMax to classify galena $(\mathrm{PbS}), \quad$ goethite $(\mathrm{FeO}(\mathrm{OH}))$, jarosite $\left(\mathrm{KFe}_{3}\left(\mathrm{SO}_{4}\right)_{2}(\mathrm{OH})_{6}\right)$, sphalerite $((\mathrm{Zn}, \mathrm{Fe}) \mathrm{S})$, pyrite $\left(\mathrm{FeS}_{2}\right)$ and to obtain rule images. The BandMax process increases classification accuracy by determining an optimal subset of bands to help you separate your targets from known background materials. The BandMax algorithm was developed by the Galileo Group, Inc. The process is based on the United States patent application titled Spectral image processing system and method for target detection and identification.

Each pixel in a rule image represents the similarity between the corresponding pixels in the hyperspectral image to a reference spectrum. These rule images are then used to govern sampling to areas with a high probability of galena, gothite, jarisite, sphalrite, pyrite occurring and to intensively sample in areas with an abundance of alunite. This effectively delineates favourable areas from unfavourable ones and provides an objective sampling scheme as an initial guideline.

\section{MATERIALS AND METHODS}

SAM (Spectral Angle Mapper) is an automated method for comparing image spectra to individual spectra or to a spectral library (Boardman and Huntington, 1996; CSES, 1992; Kruse et al., 1993). SAM assumes that the data have been reduced to apparent reflectance (true reflectance multiplied by some unknown gain factor, controlled by topography and shadows). The algorithm determines the similarity between two spectra by calculating the spectral angle between them, treating them as vectors in $\mathrm{n}-\mathrm{D}$ space, where $\mathrm{n}$ is the number of bands. Smaller angles represent closer matches to the reference spectrum.

Consider a reference spectrum and an unknown spectrum from two-band data. The two different materials are represented in a $2 \mathrm{D}$ scatter plot by a point for each given illumination, or as a line (vector) for all possible illuminations (figure 1).

Because SAM uses only the direction of the spectra, not the length, SAM is insensitive to the unknown gain factor. All possible illuminations are treated equally. Poorly illuminated pixels fall closer to the origin of the scatter plot. The colour of a material is defined by the direction of its unit vector. The angle between the vectors is the same, regardless of the length.

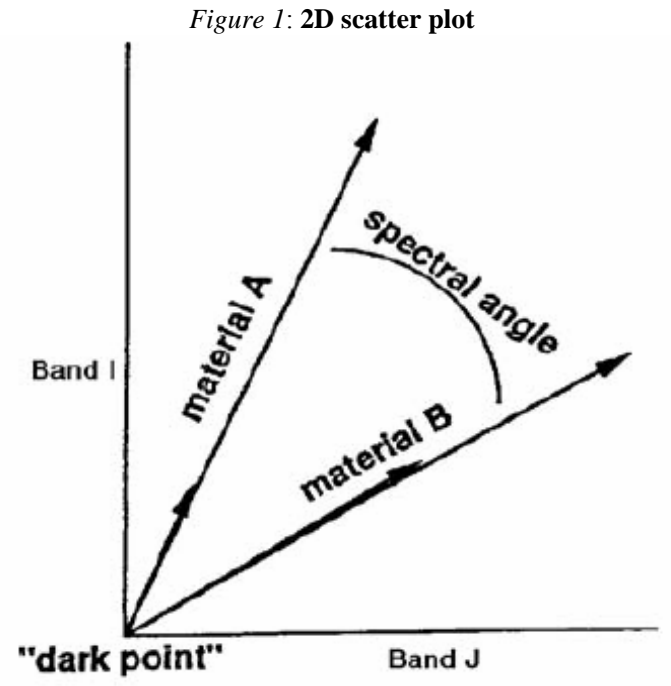

The length of the vector relates only to how fully the pixel is illuminated. The SAM algorithm generalizes this geometric interpretation to $n$-D space. SAM determines the similarity of an unknown spectrum $t$ to a reference spectrum $r$, by applying the following equation (CSES, 1992):

$$
\alpha=\cos ^{-1}\left(\frac{\vec{t} \bullet \vec{r}}{\|\vec{r}\|}\right)
$$

which also can be written as:

$$
\alpha=\cos ^{-1}\left(\frac{\sum_{i=1}^{n b} t_{i} r_{i}}{\left(\sum_{i=1}^{n b} t_{i}^{2}\right)^{1 / 2}\left(\sum_{i=1}^{n b} r_{i}^{2}\right)^{1 / 2}}\right)
$$

where $n b$ equals the number of bands in the image.

For each reference spectrum chosen in the analysis of a hyperspectral image, the spectral angle (in radians) is determined for every image spectrum (pixel). This value is assigned to the corresponding pixel in the output SAM image, one output image for each reference spectrum. The derived spectral angle maps form a new data cube with the number of bands equal to the number of reference spectra used in the mapping. Gray-level thresholding is typically used to empirically determine areas that most closely match the reference spectrum while retaining spatial coherence.

The SAM algorithm implemented in ENVI 4.3 takes as input a number of training classes, or reference spectra from ASCII files, ROIs (Region Of Interest), or spectral libraries. 
It calculates the angular distance between each spectrum in the image and the reference spectra or endmembers in $\mathrm{n}$-dimensions. The result is a classification image showing the best SAM match at each pixel and a rule image for each endmember showing the actual angular distance in radians between each spectrum in the image and the reference spectrum. Darker pixels in the rule images represent smaller spectral angles spectra that are more similar to the reference spectrum. The rule images can be used for subsequent classifications using different thresholds to decide which pixels are included in the SAM classification image. The classified image based on the SAM Maximum Angle Threshold. Decreasing this threshold usually results in fewer matching pixels (better matches to the reference spectrum). Increasing this threshold may result in a more spatially coherent image; however, the overall pixel matches will not be as good as for the lower threshold.

BandMax process allows you to select the input background spectra and displays the BandMax results and enables you to change the parameters of the process to determine an optimal solution.

BandMax rejects background data by determining a subset of spectral image bands that are useful in distinguishing between target and background spectra. Each band in the input image has a significance value calculated for it by the BandMax algorithm. The default BandMax threshold is calculated by attempting to select $25 \%$ of the input bands, but never fewer than 6 bands. This unitless value ranges from 0 to 1 , where a higher value indicates that the band has a higher probability of being able to distinguish target response from background response. The resulting band subset maximizes the contrast between selected target and backgrounds. This subset can then be used as input to a SAM analysis to reduce processing time and increase accuracy in processing the data by helping to discriminate targets from background clutter.

\section{RESULTS}

Determinations of the examined minerals based on the spectral profiles of the pixels of the area were carried out based on the USGIS standard spectral profiles (figure 2) on the barren places. Spectral profile of some pixels from the barren spots shows high reflectance in at SWIR I,II (1.5-1.8; 2.0-2.5), which was used for the determination of heavy-metal containing minerals (figure 3).

Applying the Spectral Angle Mapper with BandMax classification, the distribution of pyritic mineral (galena, pyrite and sphalerite) in the area was defined. The mineral formation occurs especially at the levees and the barren places of the Szárazvölgyi flotation sludge reservoir (figure 4).
Figure 2: USGIS standard spectral profiles as backgrounds

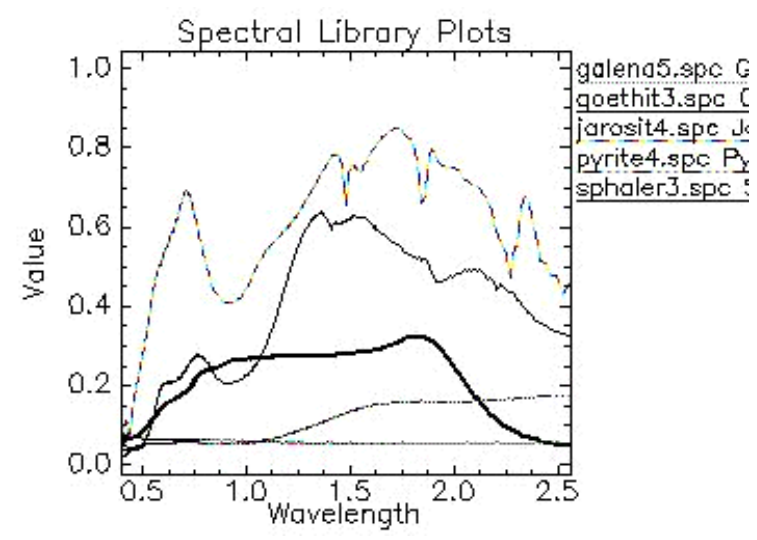

Figure 3: Spectral profile of a target pixel from a highly polluted spot

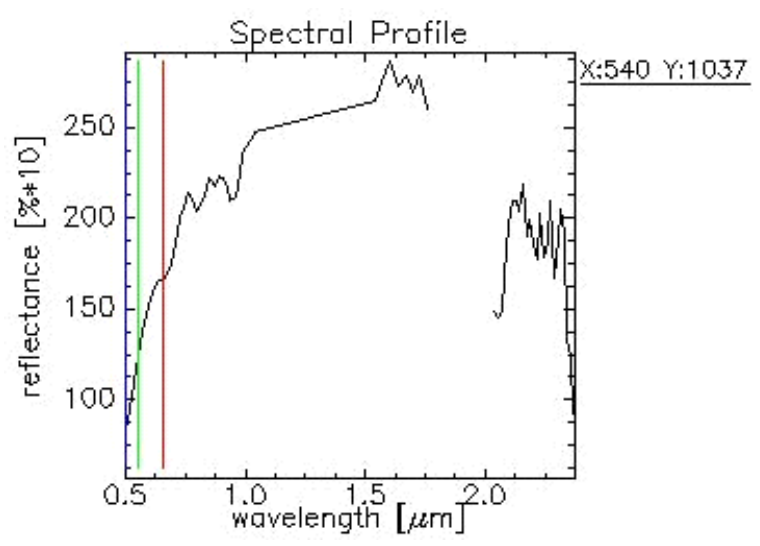

During the BandMax process, according to automatic calculations the classification was carried out with 16 significant bands, which is the $25 \%$ out of all of the used bands. The band max significance threshold at this percentage ranges between 0.48-0.69 (galena 0.69 , jarosite 0.49 , pyrite 0.65 , goethite 0.54 and sphalerite 0.48 ) which means that the 16 bands can distinguish the background and target spectra with medium confidence. After that SAM analysis was carried out with the application of the results of Band Max. The SAM maximum angle threshold was 0.10 .

With the use of hyperspectral imagery the distribution of pyritic minerals (sphalerite, pyrite galena) in the area was defined. Both of the mineral formations occur at the same distribution in flotation sludge reservoir. According to the results, jarosite and goethite have similar spatial distributions to those of sphalerite and galena, but the distribution of jarosite and goethite are not as significant as pyritic materials.

The results showed that hyperspectral remote sensing is an effective tool for the characterization and modelling the distribution of $\mathrm{Pb}, \mathrm{Zn}$ and $\mathrm{Fe}$ containing minerals at the examined heavy metal polluted sites. 
Therefore, this technology could be used for fast environmental assessment, since it provides a wide range of information quickly. Although validation (field measurements, soil samples) is necessary in order to obtain more precise results; nevertheless, the effects of vegetation and other objects should also be assessed.

\section{Figure 4: The original and the classified areas based on the standard spectral profile of 1: galena, 2: goethite, 3: jarosite, 4: pyrite, 5: sphalerite}

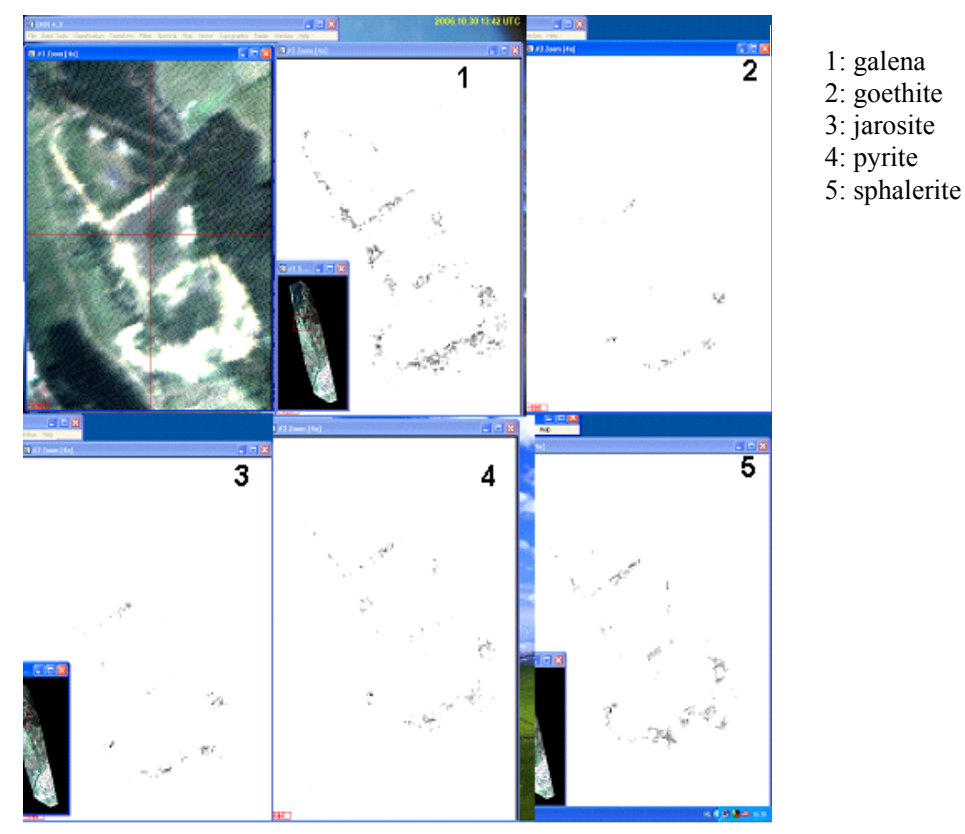

REFERENCES

Abdorhim, H.-Khalif, A.A.-Hosam, E.H.T. Bayuomi-Villányi, I.Heltai, Gy.-Kecskés， M. (2004): Szennyvíziszap-adagok hatása a növény (Triticum vulgare L.) -talaj rendszer néhány mikrobiológiai és biokémiai tulajdonságára. Agrokémia és Talajtan.53. 3-4. 413-432.

Boardman, J.W.-Huntington, J.F. (1996): Mineral Mapping with 1995 AVIRIS data: in Summaries of the Sixth Annual JPL Airborne Research Science Workshop, JPL Publication 96-4, Jet Propulsion Laboratory, v. 1. 9-11.

Burai P. (2006): Földhasználat-elemzés és növény-monitoring különbözö adattartalmú és térbeli felbontású távérzékelt felvételek alapján. Agrártudományi Közlemények, Debrecen, 22. 7-12.

CSES (Center for the Study of Earth from Space) (1992): SIPS User's Guide, The Spectral Image Processing System, v. 1.1, University of Colorado, Boulder, 74.

Clark, R.N. (1999): Clark, Spectroscopy of rocks and minerals, and principles of spectroscopy. In: Rencz, A. (Ed.) Remote sensing for the earth sciences: Manual of remote sensing. vol. 3, John Wiley and Sons, New York, 3-58 chapter 1.

Csathó P. (1994): A környezet nehézfém szennyezettsége és az agrártermelés. RISSAC, 1-176.

Jordan, G.-D'Alessandro, M. (2004): Mining, mining waste and related environmental issues.: problems and solutions in Central and Eastern European Candidate Countries, Office for Official Publications of the European Communities, 21.

Juhász, Cs.-Tamás, J.-Burai, P. (2004): Case study to evaluate good ecological status of Berettyó river watershed. III. AlpsAdria Scientific Workshop. 1-6 March 2004., Dubrovnik, Croatia. 58-61.
Kabata-Pendias, A. (2001): Trace Elements in Soils and Plants Third Edition. CRC Press, Boca Raton, FL.

Kádár I. (1991): A talajok és növények nehézfémtartalmának vizsgálata. Ed: Ligetiné Nechai, E., KTM-MTA TAKI, Budapest, 104.

Kardeván, P.-Vekerdy, Z.-Róth, L.-Sommer, S.T.-Kemper, T.H.Jordan, Gy.-Tamás, J.-Pechmann, I.-Kovács, E.-Hargitai, H.László, F. (2003): Outline of scientific aims and data processing status of the first Hungarian hyperspectral data acquisition flight campaign, HYSENS 2002 HUNGARY. 3rd EARSEL Workshop on imaging spectroscopy, 324-332.

Kruse, F.A.-Lefkoff, A.B.-Boardman, J.W.-Heidebrecht, K.B.Shapiro, A.T.-Barloon, J.P.-Goetz, A.F.H. (1993): The spectral image processing system (SIPS) - Interactive visualization and analysis of imaging spectrometer data: Remote Sensing of Environment. v. 44. 145-163.

Kruse, F.A.-Kruse, J.W.-Boardman-Huntington, J.F. (2003): Comparison of airborne hyperspectral data and EO-1 hyperion for mineral mapping, IEEE Transactions on Geoscience and Remote Sensing. 41 (2003) (6), 1388-1400.

Polder, G.-van der Heijden, G.W.A.M. (2001): Multispectral and hyperspectral image acquisition and processing. In: Q. Tong, Y. Zhu-Z. Zhu, Editors, Proceedings of SPIE. vol. 45-48.

Sabins, F.F. (1997): Remote Sensing - Principles and Interpretation. 3rd edn., W.H. Freeman, New York, 494.

Sabins, F.F. (1999): Sabins, Remote sensing for mineral exploration, Ore Geology Reviews. 14 (1999) (Issues 3-4), 157-183. 
Szucs, A.-Jordan, G.-Qvarfort, U. (2002): Geochemical modeling of acid mine drainage impact on wetland stream using landscape geochemistry, GIS and statistical methods. In: Fabbri, A.G.-Gaal, G.-McCammon, R.B.: Deposit and Geoenvironmental Models for Resource Exploitation an Environmental Security NATO Science Series, 2. Environmental Security. Kluwer Academic Publishers. 80. $425-460$.
Yan, G.-Bradshaw, A.D. (1995): The containment of toxic wastes: II. Metal movement in leachate and drainage at Parc LeadZinc Mine, North Wales, Environmental Pollution. 90.3. 379382.

Záray, Gy. (1991): Environmental assessment of the impact of mine tailing dumps in the valley of Toka-stream - case-study (in Hungarian) ELTE TTK Department of inorganic and analytical chemistry 1-86. 